Sains Malaysiana 49(7)(2020): 1509-1520

http://dx.doi.org/10.17576/jsm-2020-4907-04

\title{
Estimation of Earth Structure by Satellite Gravity Analysis of Peninsular Malaysia
}

(Anggaran Struktur Bumi melalui Analisis Graviti Satelit di Semenanjung Malaysia)

\author{
NURUl FAIRUZ DIYANA BAHRUdIN*, UMAR HAMZAH \& WAN ZUHAIRI WAN YACCOB
}

\section{ABSTRACT}

Power spectral analysis was successfully carried out on satellite gravity data along 10 East-West profiles of about 140 to $320 \mathrm{~km}$ length across Peninsular Malaysia beginning from its border with the Straits of Malacca towards the South China Sea coastline. Power spectrum curves obtained clearly indicate the presence of three major slopes corresponding to four type of materials with different dominant densities. Depth curves computed from all these profiles produced three major dominant peaks beginning with the deepest one at about 33 to $42 \mathrm{~km}$, followed by intermediate depth of 18 to $26 \mathrm{~km}$ and the shallow peaks at about 3 to $10 \mathrm{~km}$. The shallowest depth is interpreted as representing geological formation such as the Mesozoic and Palaeozoic deposits including the granite intrusion classified as basement. Underlying the basement is the upper crustal material extending to Conrad discontinuity at depth of about 18 to $26 \mathrm{~km}$. Earth materials below the Conrad discontinuity constitutes of the lower crustal material overlying the border of upper mantle at depth of 33 to $42 \mathrm{~km}$ representing the Mohorovicic discontinuity.

Keywords: Earth structures; satellite gravity data; spectral analysis

\section{ABSTRAK}

Analisis kuasa spektrum telah dijalankan ke atas data graviti satelit sepanjang 10 garis rentas timur-barat Semenanjung Malaysia. Panjang garis rentas berjulat antara 140 hingga $320 \mathrm{~km}$. Lengkung kuasa spektrum menunjukkan kehadiran tiga kecerunan utama yang mewakili empat bahan yang mempunyai ketumpatan yang berbeza. Lengkung kedalaman yang diperoleh daripada kecerunan tersebut menghasilkan tiga puncak dominan bermula daripada kedalaman maksimum 33 hingga $42 \mathrm{~km}$ diikuti dengan kedalaman sederhana 18 hingga $26 \mathrm{~km}$ dan puncak paling cetek pada kedalaman 3 hingga $10 \mathrm{~km}$. Kedalaman paling cetek ditafsirkan mewakili formasi geologi yang berusia Mesozoik dan Paleozoik termasuk granit yang dikelaskan sebagai besmen. Lapisan besmen ini menindih lapisan kerak atas yang didasari oleh satah ketakselarasan Conrad pada kedalaman 18 hingga $26 \mathrm{~km}$. Bahan bumi di bawah ketakselarasan Conrad terdiri daripada kerak bawah yang menindih sempadan mantel atas pada kedalaman 33 hingga $42 \mathrm{~km}$ yang ditafsirkan sebagai satah ketakselarasan Mohorovicic.

Kata kunci: Analisis kuasa spektrum; data graviti satelit; struktur bumi

\section{INTRODUCTION}

Earth subsurface structures have long been established by analyzing the seismic waves emanating from earthquake shocks, which moved within the globe. The inhomogeneity of earth structures may have been a strong reason to a slight difference in depth determination of crustal and mantle boundaries at different places in the world. Many geophysical researches were carried in Asian regions especially in estimating the upper crustal surface below the basement, Conrad discontinuity separating the upper and lower crust as well as the Moho discontinuity, which is demarcating the top of upper mantle (Iwasaki et al. 2013). The earth subsurface layer thickness and depths of boundaries separating them were determined basically not only by seismic but also by potential theory techniques such as gravity and magnetic modelling as well as power spectrum analysis (Prutkin \& Saleh 2009). Examples of results from land and airborne gravity and magnetic surveys were published by Asano et al. (1985), Kaila et al. (1987), Kumar et al. (2016) and Singh et al. (2015) in studying the Indian, China, and Japan continents. Almost similar results were reported by Kivior et al. (2013) and Zhu and Kanamori (2000) in the study of earth structures beneath American and European continents. In this paper, results of earth structure by power spectral analysis of satellite gravity data are presented and compared with other findings. The power spectral method on potential data has been widely used to determine the earth subsurface 
structures since it was introduced by Bhattacharyya (1966) followed by Spector and Grant (1970) as well as many other researchers such as recently by Kumar et al. (2016). In the power spectral technique the time function gravity data are converted to frequency function by Fast Fourier Transform (FFT) to be represented by Fourier series consisting of various frequencies which characterizing the source depth anomalies (Bansal \& Dimri 2001; Dimitriadis et al. 1987; Gomez et al. 2005; Spector \& Grant, 1970) and related to the geological structures including the position of crust and mantle (Treitel et al. 1971).

Maden et al. (2009) studied the orogenic belt in determining the tectonic structure and crust of east Pontide, Turkey by gravity and magnetic survey where they found the Mohorovicic thickness is about 29 to $47 \mathrm{~km}$. The thicknesses were estimated by spectral analysis technique of aeromagnetic data. A similar technique was used by Rina (2008) to determine the Mohorovicic depth ranging from 15 to $37 \mathrm{~km}$ in East Java, Indonesia. These depths can be considered as main references for this study since it is very closed to the study area. Mapping of crustal thickness by marine gravity data in South China Sea was carried out by Bai et al. (2014) resulting to the finding of Mohorovicic depth within 26 to $27 \mathrm{~km}$. Latiff and Khalil (2017) studied Moho boundary in Peninsular Malaysia by analyzing earthquake seismological data and found out that depth of Moho is about 28 to $32 \mathrm{~km}$. Finally, Macpherson et al. (2012) studied Sumatera crustal thickness ranging from 16 to $30 \mathrm{~km}$ also by earthquake seismological data without mentioning the details on Conrad and Mohorovicic discontinuity depths.

\section{MATERIALS AND METHODS}

Reduced satellite Bouguer gravity data used in this study were obtained by Earth Gravitational Model website. A total of about 1000 data points covering Peninsular Malaysia were selected for power spectral analysis and with a slight editing used as input for processing by Oasis Montaj computer software. In the power spectral analysis, Bouguer gravity data along $10 \mathrm{E}-\mathrm{W}$ profiles were chosen and stored in the input data files (Figure 1).

Spacing between each profile is about $50 \mathrm{~km}$ and the distance between each sampling points is about 1.2 to $2.6 \mathrm{~km}$. The gravity data were then transformed from the space domain into the frequency domain by means of FFT. Considering a constant density contrast (, the Fourier Transform of the field gravity data $\mathrm{h}(\mathrm{x})$, can be written as

$$
\Delta g(k)=\left(\frac{2 G \Delta \rho}{k}\right) \int_{-\infty}^{\infty} e^{-j k x} e^{-|k| h(x)} d x
$$

where $k$ is the wavenumber (=1/wavelength); and G is the international gravity constant (Mishra \& Pederson 1982). In this study, the value of density contrast $(\Delta \rho)$ used for determining the Moho discontinuity is $0.2 \mathrm{gm} / \mathrm{cc}$, while for estimating the Conrad discontinuity the density contrast
$(\Delta \rho)$ used is $0.4 \mathrm{gm} / \mathrm{cc}$. This equation can be simplified by expanding the exponential and taking into account only the first order and written as

$$
\Delta g(k)=2 G \Delta \rho e^{-j|k| h_{0}} \Delta h k
$$

This equation directly relating between the computed gravity spectra and the unknown mean depth, $h_{o}$, of the interface, perturbated by the term $\Delta \mathrm{h}(\mathrm{k})$. The non-linear effect of $\Delta \mathrm{h}(\mathrm{k})$ is negligible in case of long wavelengths and the relation between gravity spectra and depth becomes almost log-linear (Mishra \& Pederson 1982). Therefore, depth to the source of anomaly can be estimated from the slope of the spectra. In the processing stage, the MAGMAP operator is chosen for the data to be gridded. The gridded data are then transformed by applying FFT filter into the wave number domain by assuming density contrast $(\Delta \rho)$ as constant. This transformed data will be used to calculate and display the radially averaged energy power spectrum. The depth to the source of anomaly is determined by the equation given as

$$
h=-\frac{s}{4 \pi}
$$

where $h$ is the depth; and $s$ is the slope of the log (energy) spectrum.

\section{RESULTS AND DISCUSSION}

In general, the anomaly source depth range computed for each line is from 0.03 to a maximum of about 42 $\mathrm{km}$. The deepest depth observed in Profile7 $\left(100.62^{\circ} \mathrm{E}\right.$, $4.52^{\circ} \mathrm{N}$ ) situated in the northern part of Peninsular Malaysia can be associated with the deepest upper mantle surface and hence the thickest crustal layer in the study area. Basically similar pattern are observed in all profiles of radially averaged energy spectrum curves which are displaying three major slopes interpreted as representing deep, intermediate and shallow anomaly depth source. Profile A with length $(145 \mathrm{~km})$ of located at longitude $102.8^{\circ} \mathrm{E}$ and latitude of $1.8^{\circ} \mathrm{N}$, which is in the most southern part of Peninsular Malaysia, indicates the presence of three major slopes with different depth. The depths calculated from the spectral curve are shown in Figure 2(a), which are estimated at 20.63 and $8.0 \mathrm{~km}$. These depths represent boundaries of different geological properties estimated as Conrad discontinuity and top of basement. Figure 2(b) shows similar spectral analysis curve and depth estimate from it representing Profile B located at longitude $102.11^{\circ} \mathrm{E}$ and latitude of $2.26^{\circ} \mathrm{N}$ with length of $207 \mathrm{~km}$. As for this profile, the maximum peak calculated from the slopes is $24.58 \mathrm{~km}$ which also equivalent to Conrad discontinuity separating the upper and lower crustal materials. The second highest peak is detected at $11.48 \mathrm{~km}$ depth, which can be correlated with top of basement layer. Average of basement top layer is about $9 \mathrm{~km}$. 
Profile C with length of $240 \mathrm{~km}$ located further north of Profile B along longitude of $101.45^{\circ} \mathrm{E}$ and latitude of $2.71^{\circ} \mathrm{N}$ is shown in Figure 2(c). The power spectrum curve and the depth slope give much deeper depth of $33.39 \mathrm{~km}$ interpreted as separating upper mantle and lower crustal materials equivalent to Moho discontinuity surface. The second highest peak was observed at 17.21 to $18 \mathrm{~km}$ representing Conrad discontinuity while the numerous lower peaks were observed between 3.89 and $10 \mathrm{~km}$ representing basement layer. Moho depth was not obtained in Profile A and B due to shorter profile length compared to Profile C. Profile D located further north of Profile C along longitude of $101.31^{\circ} \mathrm{E}$ and latitude of $3.15^{\circ} \mathrm{N}$ is shown in Figure 2(d) displaying three slopes of power spectrum curve with three major peaks representing depths of boundaries separating the earth structures. The highest and maximum depth peak is at about $36.54 \mathrm{~km}$ interpreted to be representing Moho discontinuity separating the upper mantle and the lower crustal materials. The Conrad discontinuity is estimated from the lower peak at depth of $21.49 \mathrm{~km}$ and the basement top is estimated from many shallow peaks below $10 \mathrm{~km}$ depth. Profile E with length of $265 \mathrm{~km}$ located at longitude $100.98^{\circ} \mathrm{E}$ and latitude of $3.61^{\circ} \mathrm{N}$ (Figure 2(e)). The highest and maximum depth peak is at about $33.73 \mathrm{~km}$ interpreted to be representing Moho discontinuity separating the upper mantle and the lower crustal materials. The Conrad discontinuity is estimated from the lower peak at depth of $21.80 \mathrm{~km}$ and the basement top is estimated from many shallow peaks below $10 \mathrm{~km}$ depth. Profile F located at longitude $100.76^{\circ} \mathrm{E}$ and latitude of $4.06^{\circ} \mathrm{E}$ with length of $294 \mathrm{~km}$ is shown in Figure 2(f). The highest and maximum depth peak is at about 33.31 $\mathrm{km}$ interpreted to be representing Moho discontinuity separating the upper mantle and the lower crustal materials. Meanwhile for the second peak is observed at depth of 20 $\mathrm{km}$ representing the Conrad discontinuity and the basement is estimated at depth below $10 \mathrm{~km}$.

Profile $\mathrm{G}$ is the longest profile with length of $315 \mathrm{~km}$ (Figure $2(\mathrm{~g})$ ) located at longitude $100.26^{\circ} \mathrm{E}$ and latitude $4.52^{\circ} \mathrm{N}$ which associated with the upper mantle layer at depth of $41.48 \mathrm{~km}$. This depth interpreted as Moho discontinuity, while for Conrad discontinuity is interpreted at depth of $26.01 \mathrm{~km}$ which separating the upper and lower crust layer and the basement is estimated at depth below $10 \mathrm{~km}$. Profile $\mathrm{H}$ located further north of Profile $\mathrm{G}$ along longitude of $100.4^{\circ} \mathrm{E}$ and latitude of $4.96^{\circ} \mathrm{N}$ with length of $326 \mathrm{~km}$ is shown in Figure 2(h). Figure 2(h) displaying three slopes of power spectrum curve with three major peaks representing depths of boundaries separating the earth structures. The highest and maximum depth peak is at about $38.81 \mathrm{~km}$ interpreted to be representing Moho discontinuity separating the upper mantle and the lower crustal materials. The Conrad discontinuity is estimated from the lower peak at depth of $22.9 \mathrm{~km}$ and the basement top is estimated from many shallow peaks from 5.09 to $10 \mathrm{~km}$ depth. Profile I located at longitude $100.16^{\circ} \mathrm{E}$ and latitude $5.42^{\circ} \mathrm{N}$ is shown in Figure 2(i). The highest and maximum depth peak is at about $34.89 \mathrm{~km}$ interpreted to be representing Moho discontinuity separating the upper mantle and the lower crustal materials. The Conrad discontinuity is estimated from the lower peak at depth of $21.49 \mathrm{~km}$ and the basement top is estimated from many shallow peaks below $10.39 \mathrm{~km}$ depth. Profile J located at longitude $100.34^{\circ} \mathrm{E}$ and latitude $5.87^{\circ} \mathrm{N}$ only has 2 peaks at depth 28.89 and $8.64 \mathrm{~km}$ represent the Conrad discontinuity and basement (Figure 2(j)).

Depth curves can be classified into three dominant depth group based on its peak position. The highest peak with maximum depth of about 33 to $42 \mathrm{~km}$ appeared in 7 profiles with the exception of profile 1,2 , and 10 which are located in the most southern and northern part of the study area. The highest peak observed correspond to the deepest part of earth materials which is most likely related to the Moho discontinuity. The second peak observed in the depth curve almost by all profiles ranging from 18 to $26 \mathrm{~km}$ is interpreted as the Conrad discontinuity. The numerous remaining shallow peaks in the depth-wave number panels ranging from 0.03 to $18 \mathrm{~km}$ can be interpreted as maximum depth of basement rocks consisting of Mesozoic, Paleozoic and igneous intrusion (Table 1).

Similar range of depths were also observed by Loke et al. (1983) and Ryall (1982) based on gravity modelling along east-west between Kuala Selangor to Kuantan (Table 2). Depth of basement and Conrad discontinuity by Loke et al. (1983) and Ryall (1982) were 10 to 12 $\mathrm{km}$ and 18 to $20 \mathrm{~km}$, respectively, meanwhile depth of Moho discontinuity was not detected. Asano et al. (1985) used seismic technique to discover depth of basement, Conrad and Moho discontinuities in Honshu, Japan to be approximately about 3 to $8 \mathrm{~km}, 15$ to $20 \mathrm{~km}$, and 35 to $40 \mathrm{~km}$, respectively. Similar seismic study by Kaila et al. (1987) in India found equivalent depth of basement, Conrad and Moho discontinuities. Mooney et al. (1998) in the study of global subsurface structure found the maximum of crustal thickness around South East Asia to be about $30 \mathrm{~km}$ depth. Rina (2008) studied crustal layers in Jawa Timur, Indonesia which is very close to our study area by power spectrum technique of gravity data found that Moho discontinuity depth is about $25.6 \mathrm{~km}$. This depth is about $7 \mathrm{~km}$ less than our finding which is at $33 \mathrm{~km}$ depth. Kieling and Roessler (2011) and Kumar et al. (2016) also observed similar depth of Moho discontinuity at 25 to $38 \mathrm{~km}$ in Peninsular Malaysia and 30 to $32 \mathrm{~km}$ in India by using seismic technique and power spectral analysis on gravity data. All these case studies further confirm the validity of our result regarding the crustal-mantel depth. Table 2 shows the comparison of the average results of this study with the other findings.

Figure 3 shows the variations of basement, Conrad and Mohorovicic depths obtained from spectral analysis of 10 profiles from south to north of Peninsular Malaysia. Mohorovicic depth varies from 33 to $42 \mathrm{~km}$ below the 
surface along 7 profiles with the exception of last three profiles where the maximum depth observed were very shallow from 20 to $25 \mathrm{~km}$ which are most likely not considered as Moho depth. Conrad discontinuity were shown in Figure 3 as depth variations from 19 to $25 \mathrm{~km}$. Basement depth variations are almost consistent between
5 and $8 \mathrm{~km}$ depth. The difference of lower crustal layer depths of about $8.73 \mathrm{~km}$ around the Moho discontinuity located at $4 .-4.5^{\circ} \mathrm{N}$ can be used as an indicator of possible rifting event in that layer which probably caused the seismic activities such as minor tremors and active faults at Bukit Tinggi, Pahang.

FIGURE 1. Bouguer gravity anomaly map of Peninsular Malaysia with position of traverse profiles used in the power spectral analysis 


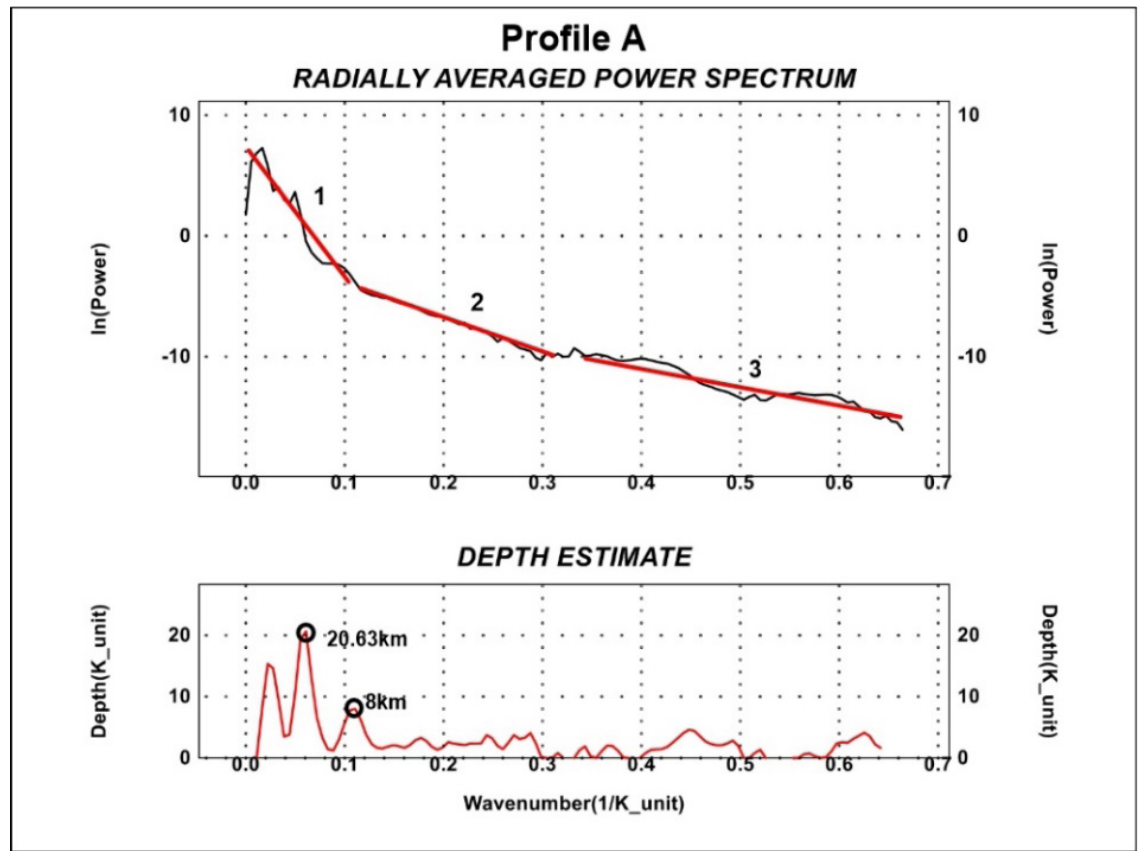

FIGURE 2. (a) shows the radially averaged power spectrum of profile A indicating the dominant slope of 1 to 3 and the depth curve indicating the depth of the slope

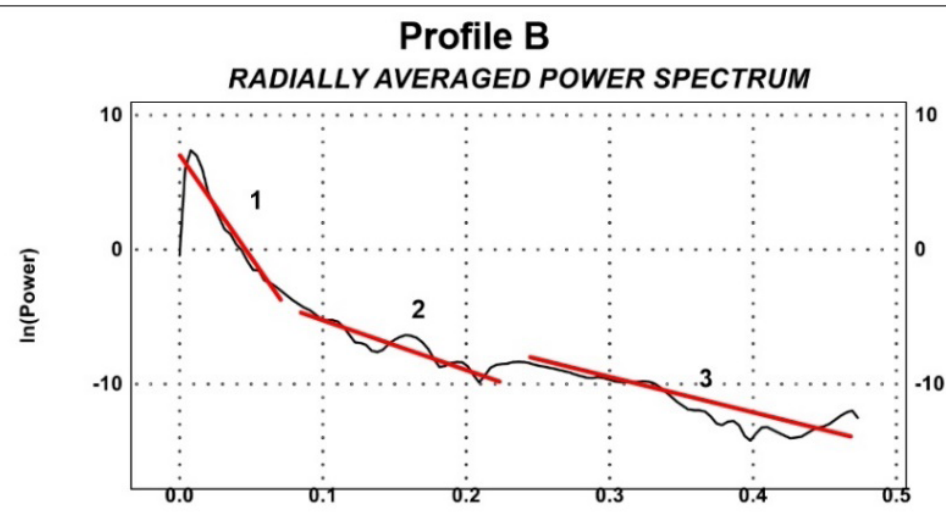

DEPTH ESTIMATE

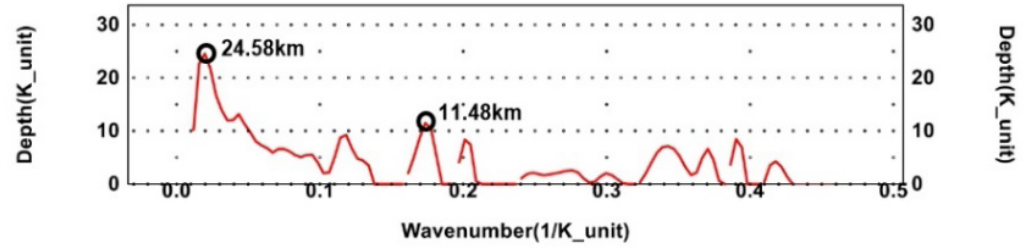

FIGURE 2. (b) shows the radially averaged power spectrum of profile $\mathrm{B}$ indicating the dominant slope of 1 to 3 and the depth curve indicating the depth of the slope 


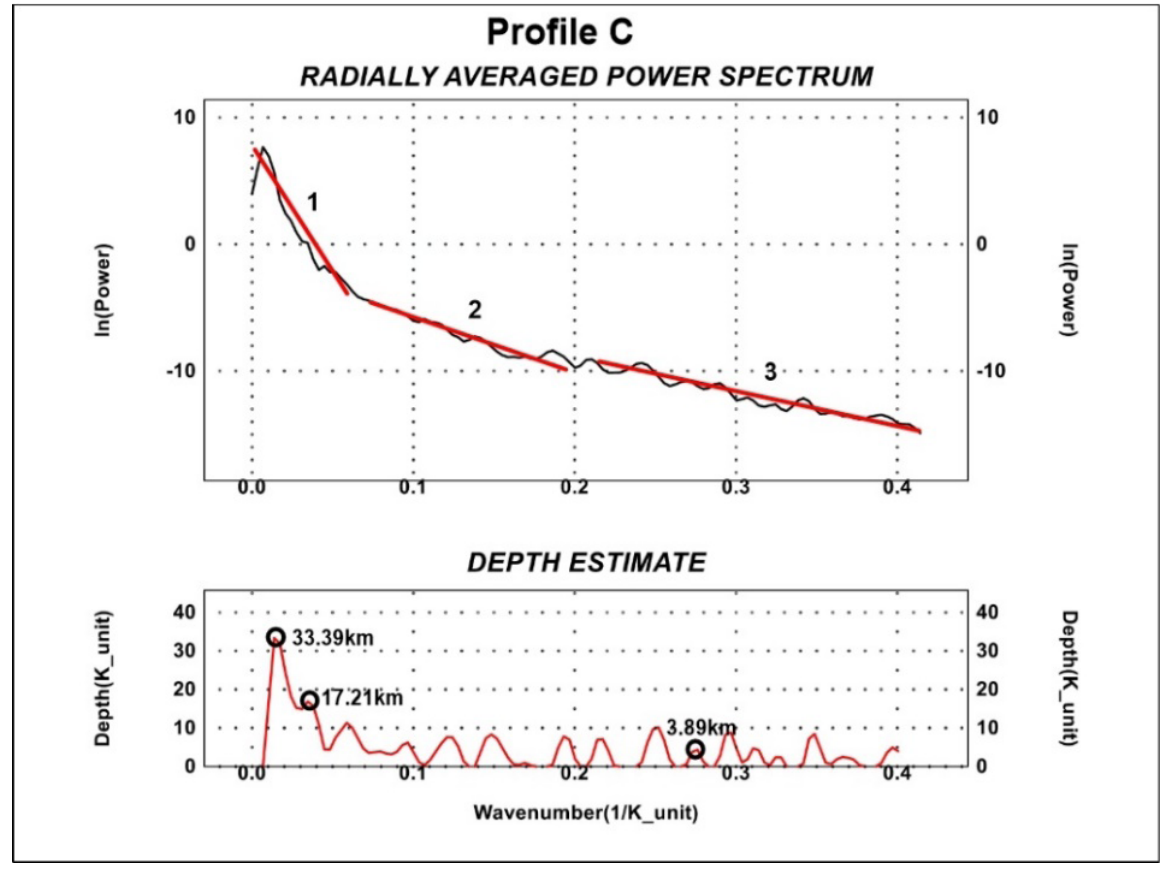

FIGURE 2. (c) shows the radially averaged power spectrum of profile $C$ indicating the dominant slope of 1 to 3 and the depth curve indicating the depth of the slope

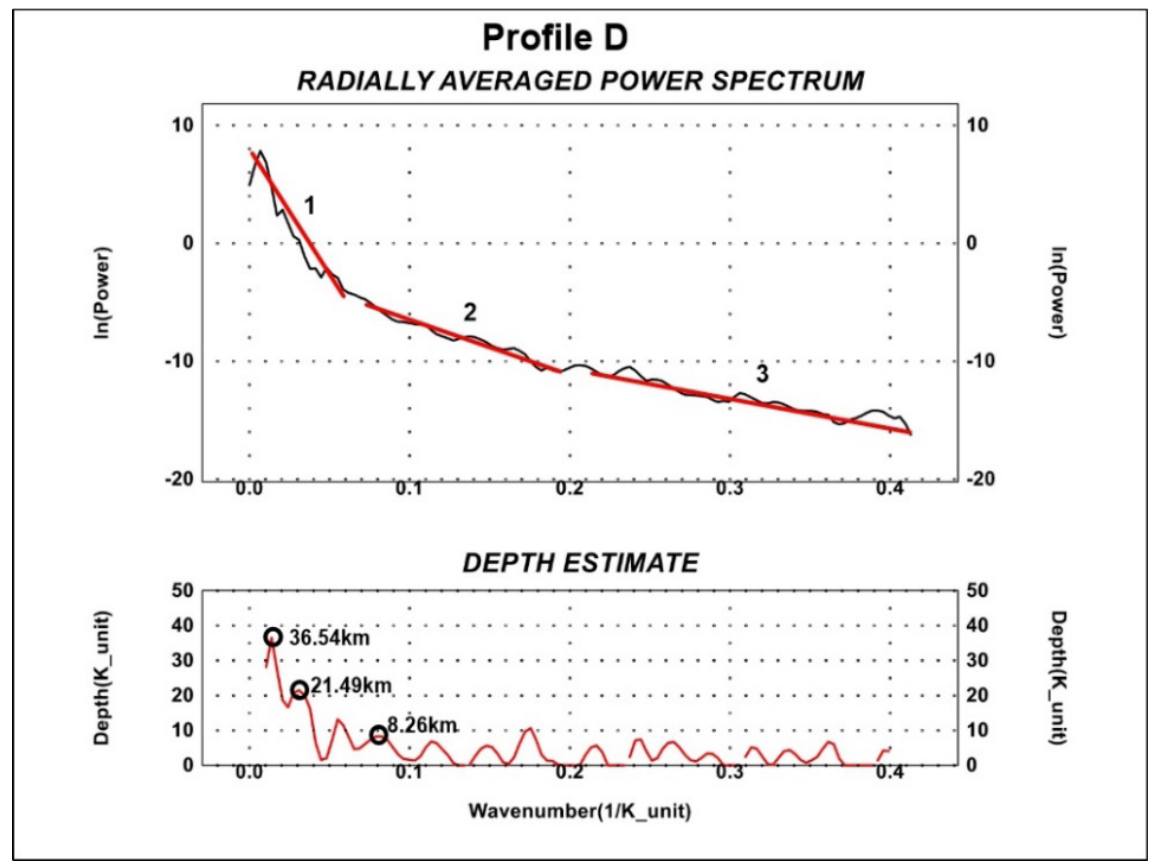

FIGURE 2. (d) shows the radially averaged power spectrum of profile D indicating the dominant slope of 1 to 3 and the depth curve indicating the depth of the slope 


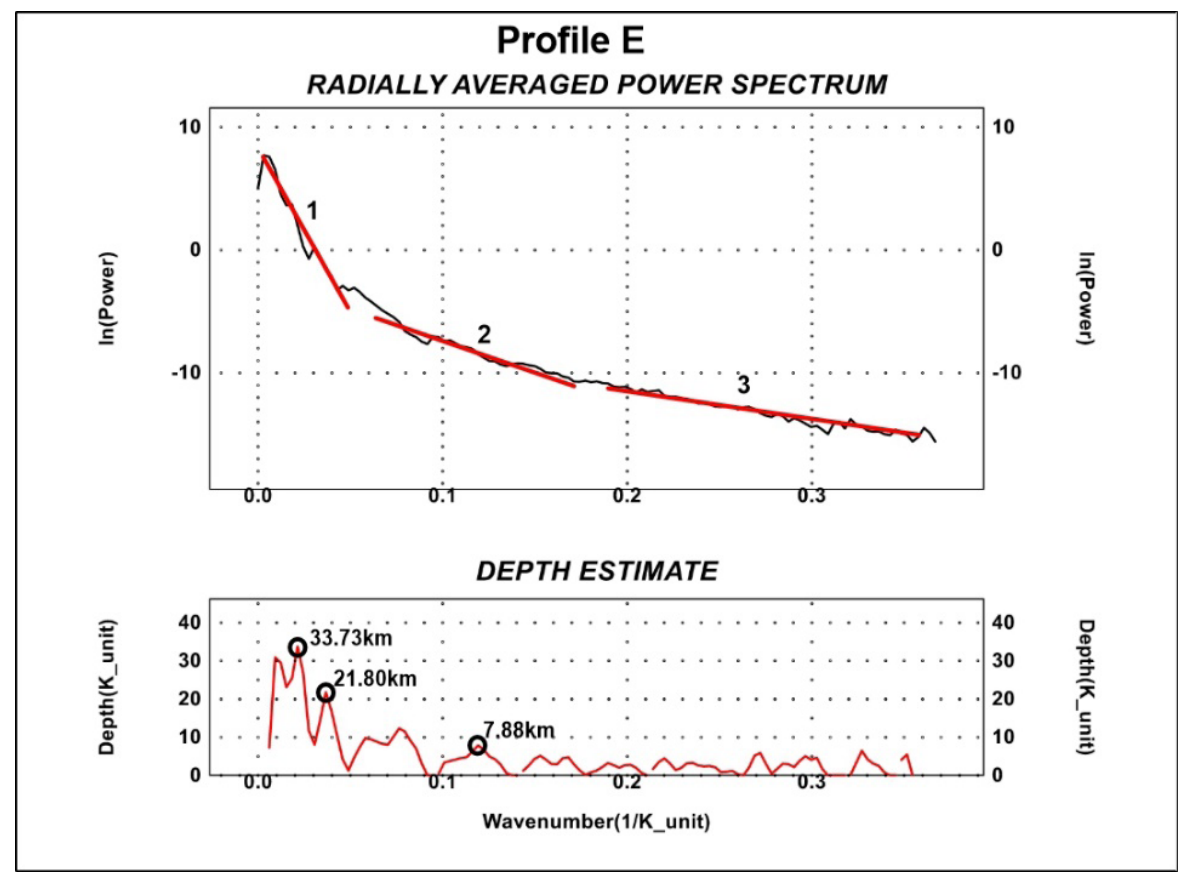

FIGURE 2. (e) shows the radially averaged power spectrum of profile $E$ indicating the dominant slope of 1 to 3 and the depth curve indicating the depth of the slope

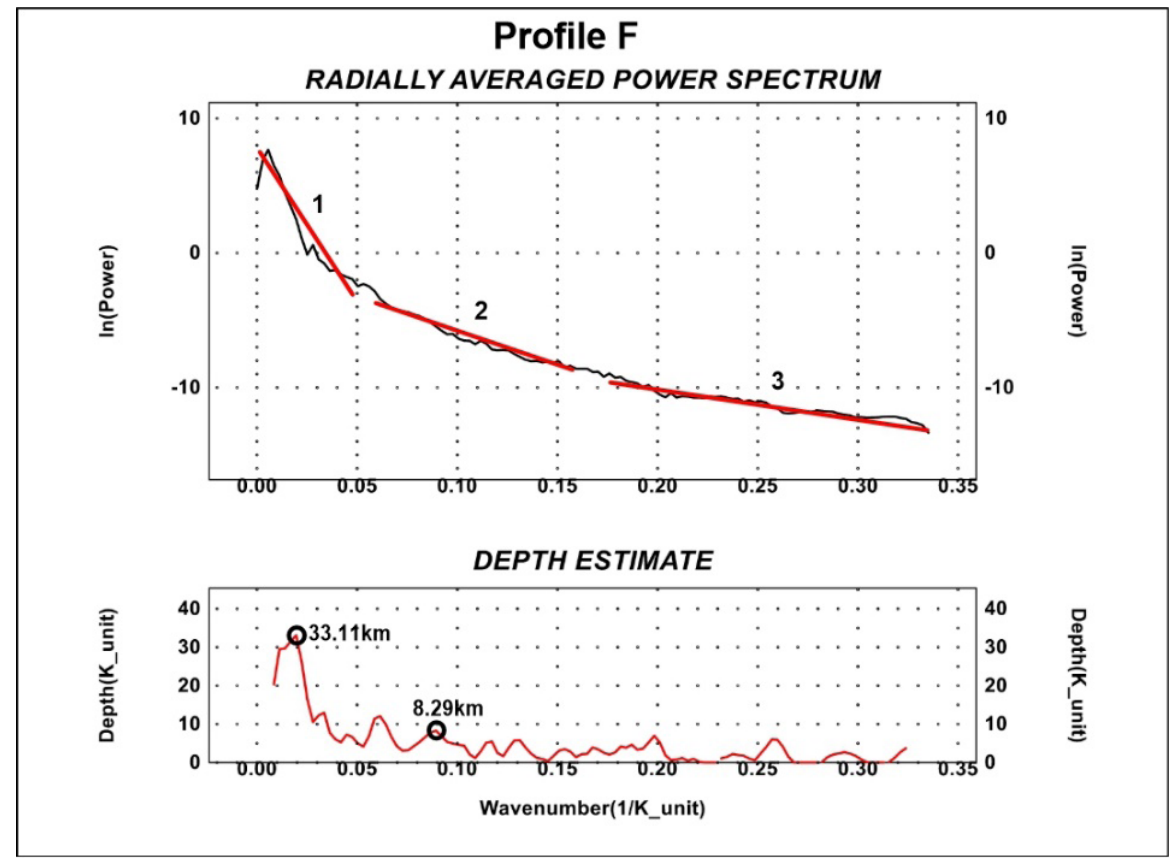

FIGURE 2. (f) shows the radially averaged power spectrum of profile A indicating the dominant slope of 1 to 3 and the depth curve indicating the depth of the slope 


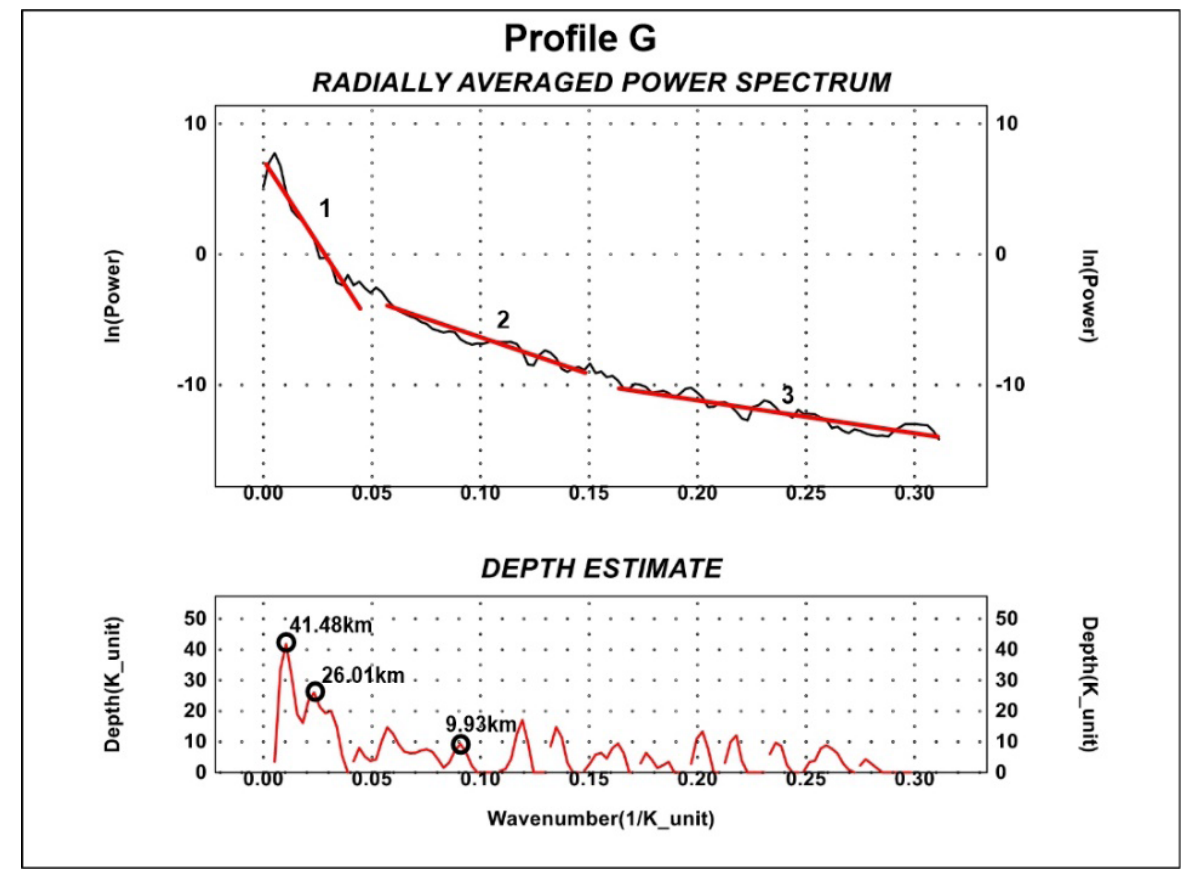

FIGURE 2. (g) shows the radially averaged power spectrum of profile $\mathrm{G}$ indicating the dominant slope of 1 to 3 and the depth curve indicating the depth of the slope

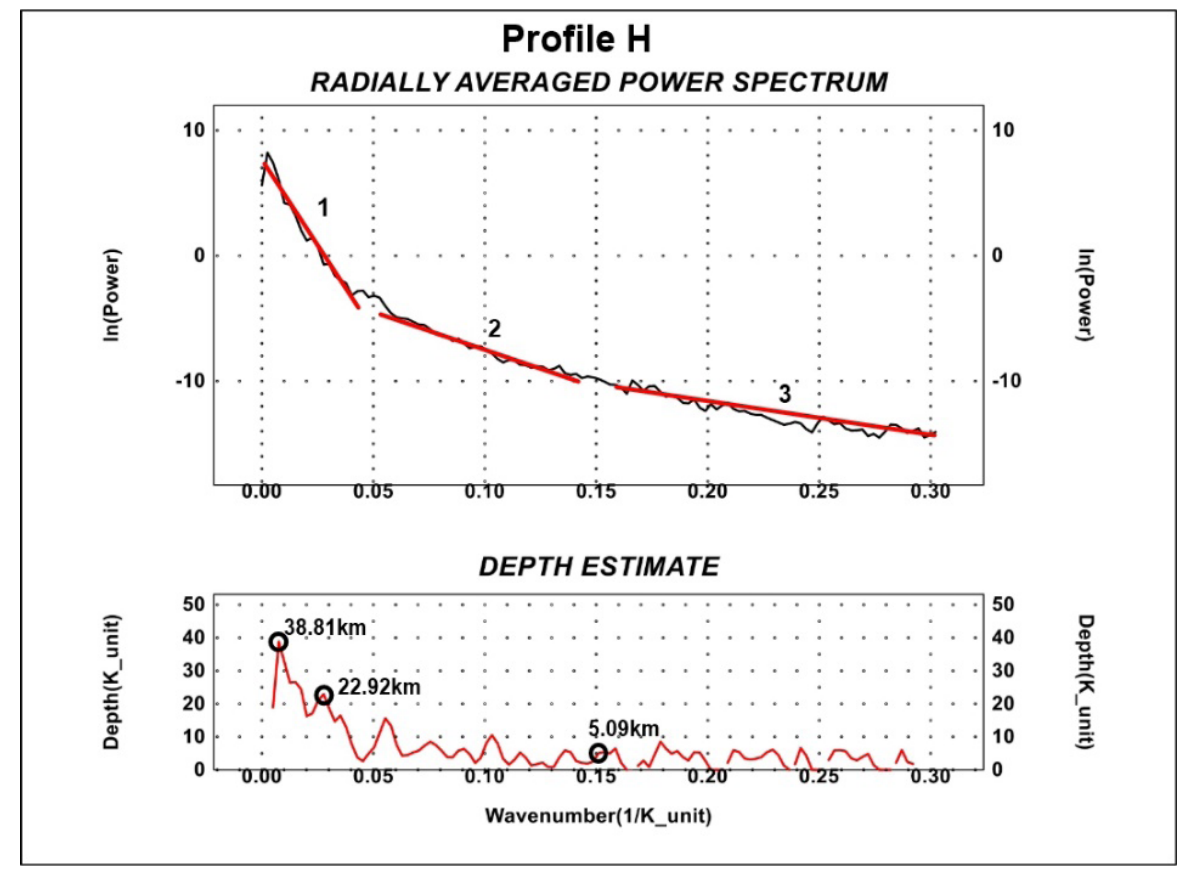

FIGURE 2. (h) shows the radially averaged power spectrum of profile $\mathrm{H}$ indicating the dominant slope of 1 to 3 and the depth curve indicating the depth of the slope 


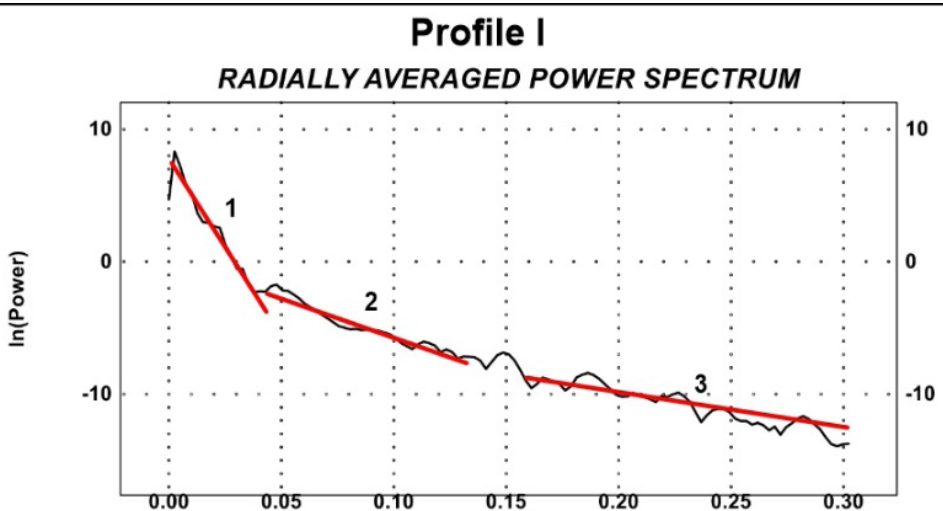

DEPTH ESTIMATE

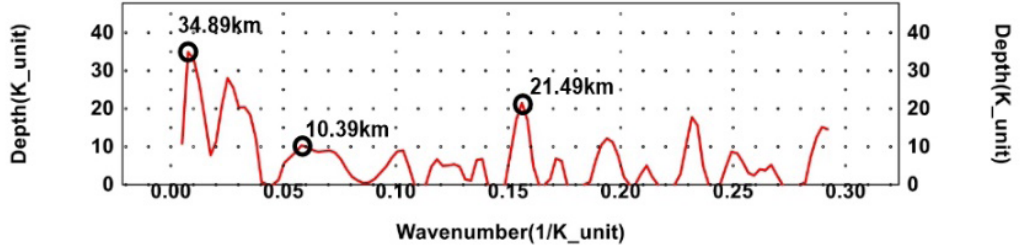

FIGURE 2. (i) shows the radially averaged power spectrum of profile I indicating the dominant slope of 1 to 3 and the depth curve indicating the depth of the slope

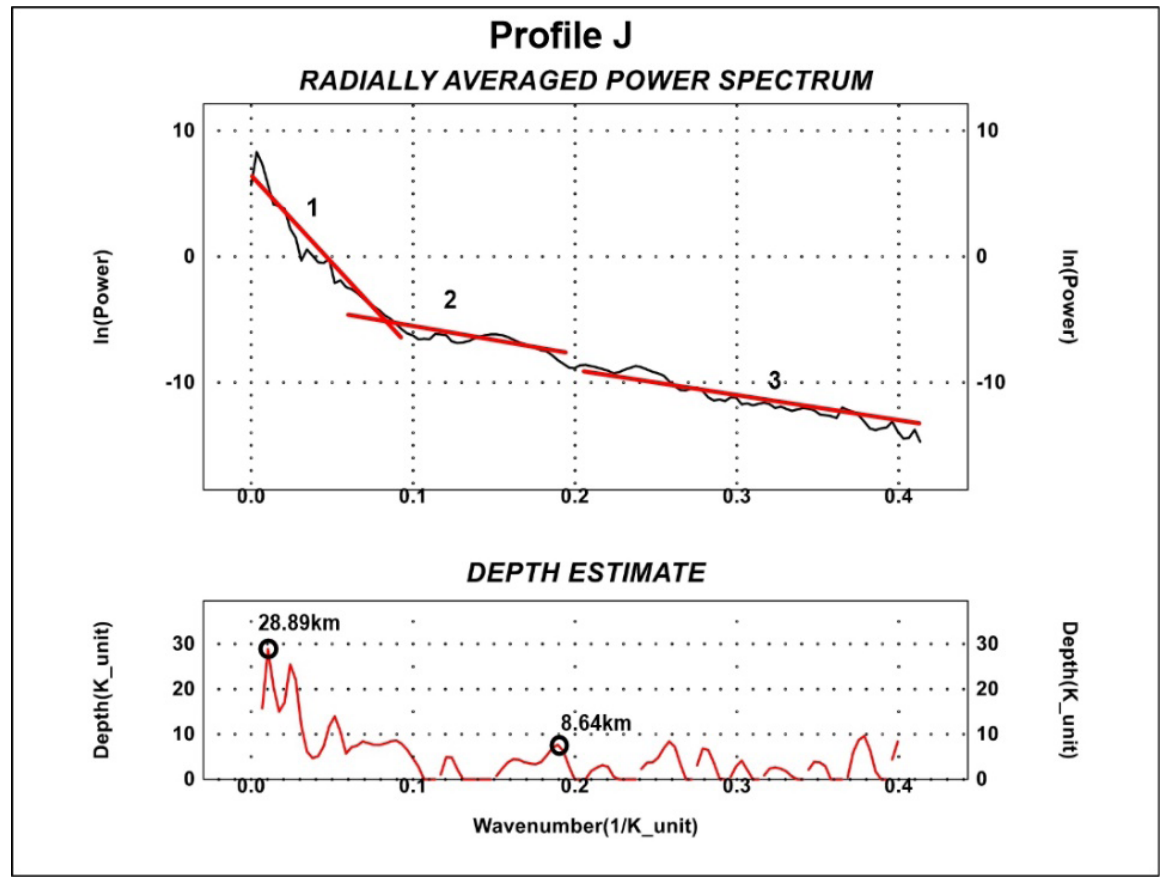

FIGURE 2. (j) shows the radially averaged power spectrum of profile $J$ indicating the dominant slope of 1 to 3 and the depth curve indicating the depth of the slope 


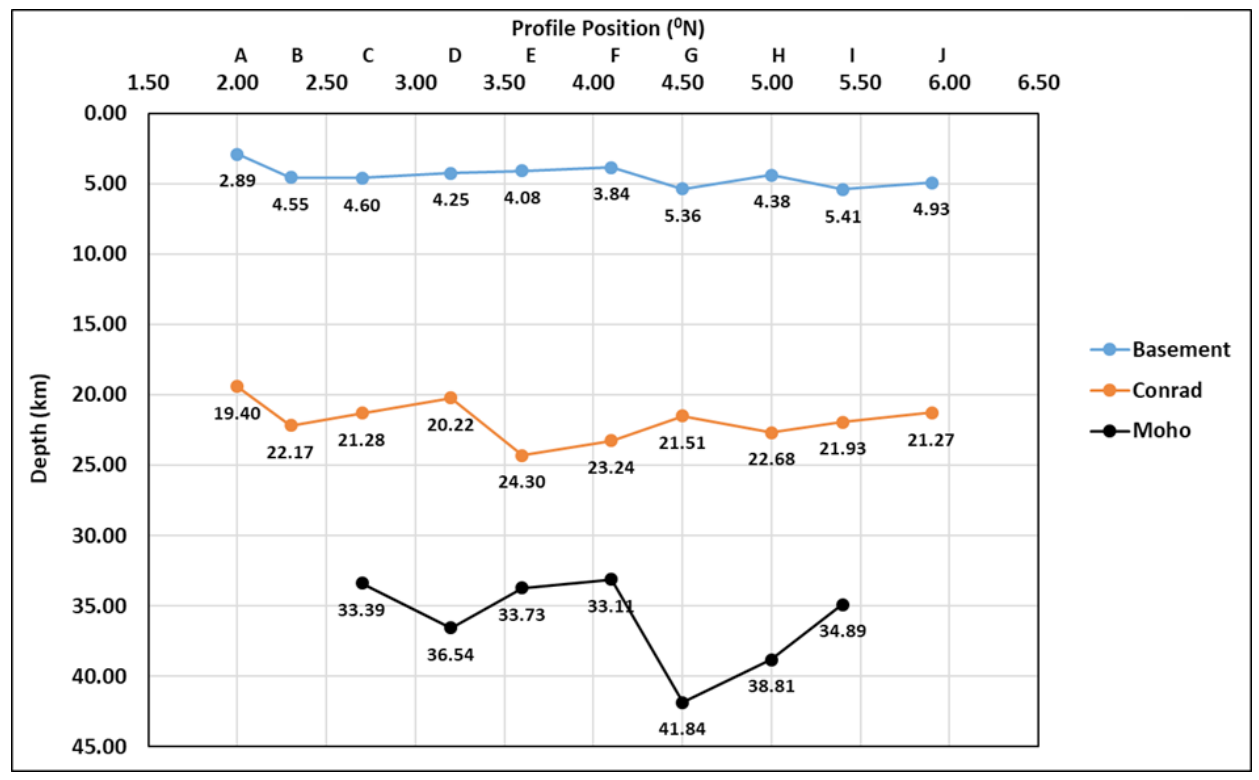

FIGURE 3. Depth variations of basement, Conrad, and Mohorovicic discontinuities based on spectral analysis of each profile from N-S of Peninsular Malaysia

TABLE 1. Shows the depth range of Conrad, and Moho discontinuity obtained by profile 1 to 10 in the study area

\section{Peak/Depth (km)}

\begin{tabular}{|c|c|c|c|}
\hline Profile & Basement & Conrad discontinuity & Mohorovicic discontinuity \\
\hline A & 9.32 & 20 & - \\
\hline B & 9.84 & 25 & - \\
\hline $\mathrm{C}$ & 10.04 & 18 & 33.39 \\
\hline $\mathrm{D}$ & 9.66 & 20 & 36.54 \\
\hline E & 9.77 & 22 & 33.73 \\
\hline $\mathrm{F}$ & 9.93 & 20 & 33.11 \\
\hline G & 9.93 & 26 & 41.84 \\
\hline $\mathrm{H}$ & 8.55 & 22 & 38.81 \\
\hline I & 9.77 & 20 & 34.89 \\
\hline $\mathrm{J}$ & 9.61 & 25 & - \\
\hline
\end{tabular}

TABLE 2. Results of average basement depths, Conrad, and Moho discontinuities obtained by several researchers as compared to this study

\begin{tabular}{|c|c|c|c|c|}
\hline \multirow[b]{2}{*}{ Researcher/Area } & \multirow[b]{2}{*}{ Method } & \multicolumn{3}{|c|}{ Discontinuity } \\
\hline & & $\begin{array}{l}\text { Basement depth } \\
(\mathrm{km})\end{array}$ & $\begin{array}{l}\text { Conrad depth } \\
(\mathrm{km})\end{array}$ & $\begin{array}{l}\text { Moho depth } \\
\quad(\mathrm{km})\end{array}$ \\
\hline $\begin{array}{l}\text { Ryall } 1982 \text { \& Loke et } \\
\text { al. } 1983 \text { (Peninsular } \\
\text { Malaysia) }\end{array}$ & $\begin{array}{l}\text { Modelling using } \\
\text { potential data }\end{array}$ & $10-12$ & $18-20$ & - \\
\hline
\end{tabular}




\begin{tabular}{|c|c|c|c|c|}
\hline $\begin{array}{l}\text { Asano et al. } 1985 \\
\text { (Honshu, Japan) }\end{array}$ & Seismic & $3-8$ & $15-20$ & $35-40$ \\
\hline $\begin{array}{l}\text { Kaila et al. } 1987 \\
\text { (Mahanadi Delta, } \\
\text { India) }\end{array}$ & Seismic & 6 & $17.5-20.5$ & $30-34$ \\
\hline $\begin{array}{l}\text { Mooney et al. } 1998 \\
\text { (Global) }\end{array}$ & Seismic & - & - & 30 \\
\hline $\begin{array}{l}\text { Rina } 2008 \text { (Jawa } \\
\text { Timur, Indonesia) }\end{array}$ & $\begin{array}{l}\text { Power Spectrum } \\
\text { on gravity data }\end{array}$ & 2.7 & - & 25.6 \\
\hline $\begin{array}{l}\text { Kieling \& Roessler } \\
2011 \\
\text { (Peninsular Malaysia) }\end{array}$ & Seismic & $2-6$ & $12-19$ & $25-38$ \\
\hline $\begin{array}{l}\text { Kumar et al. } 2016 \\
\text { (Odisha, India) }\end{array}$ & $\begin{array}{l}\text { Spectral Analysis } \\
\text { on the gravity data }\end{array}$ & 8 & $14-15$ & $30-32$ \\
\hline $\begin{array}{l}\text { Our Study } \\
\text { (Peninsular Malaysia) }\end{array}$ & $\begin{array}{l}\text { Power Spectrum } \\
\text { on gravity data }\end{array}$ & $3-10$ & $18-26$ & $33-42$ \\
\hline
\end{tabular}

\section{CONCLUSION}

Spectral analysis technique of Bouguer gravity data in Peninsular Malaysia showed three spectacular dominant slopes associated to depths of basement, Conrad, and Mohorovicic discontinuities at about 3 to $10 \mathrm{~km}, 18$ to $26 \mathrm{~km}$, and 33 to $42 \mathrm{~km}$, respectively. These depths are in good agreement as obtained by seismological, gravity and magnetic modelling techniques.

\section{ACKNOWLEDGEMENTS}

It is a pleasure to acknowledge our colleagues at Universiti Kebangsaan Malaysia (UKM) and Agensi Nuklear Malaysia for their valuable suggestions and comments during the preparation of this manuscript.

\section{REFERENCES}

Asano, S., Wada, K., Yoshii, Y., Hayakawa, M., Misawa, Y., Moriya, T., Kanazawa, T., Murakami, H., Suzuki, F., Kubota, R. \& Suyehiro, K. 1985. Crustal structure in the northern part of the Philippine Sea plate as derived from seismic observations of Hatoyama-off Izu Peninsula explosions. Journal of Physics of the Earth 33(3): 173-189.

Bai, Y., Williams, S.E., Muller, R.D., Liu, Z. \& Hosseinpour, M. 2014. Mapping crustal thickness using marine gravity data: Methods and uncertainties. Geophysics 79(2): 27-36.

Bansal. A.R. \& Dimri, V.P. 2001. Depth estimation from the scaling power spectral density of nonstationary gravity profile. Pure and Applied Geophysics 158(4): 799-812.

Bhattacharyya, B.K. 1966. Continuous spectrum of the total magnetic anomaly due to a rectangular prismatic body. Geophysics 31(1): 97-121.

Dimitriadis, K., Tselentis, G.A. \& Thanassoulas, K. 1987. A basic program for 2-D spectral analysis of gravity data and source-depth estimation. Computers \& Geosciences 13(5): 549-560.

Gomez-Ortiz, D. \& Agarwal, B.N.P. 2005. 3DINVER.M: A MATLAB program to invert the gravity anomaly over a 3D horizontal density interface by Parker-Oldenburg's algorithm. Computers \& Geosciences 31(4): 513-520.

Iwasaki, T., Levin, V., Nikulin, A. \& Idaka, T. 2013. Constraints on the Moho in Japan and Kamchatka. Tectonophysics 609(2013): 184-201.

Kaila, K.L., Tewari, H.C. \& Mall, D.M. 1987. Crustal structure and delineation of Gondwana basin in the Mahanadi delta area, India from deep seismic soundings. Journal of the Geological Society of India 29(3): 293-308.

Kieling, K., Roessler, D. \& Krueger, F. 2011. Receiver function study in Northern Sumatra and the Malaysian Peninsula. Journal of Seismology 15(2): 235-259.

Kivior, I., Boyd, D., Tucker, D., Markham, S., Vaughan, F., Hagos, F. \& Mellon, L. 2013. Deep crustal structures interpreted from potential field data along the deep seismic sounding transect across Olympic Dam, South Australia. ASEG Extended Abstracts 2013(1): 1-4.

Kumar, A., Roy, P.N.S. \& Das, L.K. 2016. Vertical density contrast and mapping of basement, Conrad and Moho morphologies through 2D spectral analysis of gravity data in and around Odisha, India. Journal of Asian Earth Sciences 124(2016): 181-190.

Latiff, A.A.H. \& Khalil, A.E. 2017. Crustal thickness of NorthWest Peninsular Malaysia region inferred from receiver function analysis. Seventh International Conference on Geotechnique, Construction Materials and Environment, Mie, Japan. pp. 1-6.

Loke, M.H., Lee, C.Y. \& van Klinken, G. 1983. Interpretation of regional gravity and magnetic data in Peninsular Malaysia. Bulletin of the Geological Society of Malaysia 16: 1-22.

Macpherson, K.A., Hidayat, D., Feng, L. \& Goh, S.H. 2013. Crustal thickness and velocity structure beneath Singapore's seismic network. Journal of Asian Earth Sciences 64(2013): 245-255. 
Maden, N. Gelisli, K., Eyuboglu, Y. \& Bekta, O. 2009. Determination of tectonic and crustal structure of the Eastern Pontide orogenic belt (NE Turkey) using gravity and magnetic data. Pure and Applied Geophysics 166(12): 1987-2006.

Mishra, D.C. \& Pedersen, L.B. 1982. Statistical analysis of potential fields from subsurface reliefs. Geoexploration 19(4): 247-265.

Mooney, W.D., Laske, G. \& Masters, G. 1998. A new global crustal model at $5 \times 5$ degrees: CRUST5.1. Journal of Geophysical Research 103(B1): 727-747.

Prutkin, I. \& Saleh, A. 2009. Gravity and magnetic data inversion for 3D topography of the Moho discontinuity in the Northern Red Sea area, Egypt. Journal of Geodynamics 47(5): 237-245.

Ryall, P.J.C. 1982. Some thoughts on the crustal structure of Peninsular Malaysia - results of a gravity traverse. Bulletin of the Geological Society of Malaysia 15: 9-18.

Singh. A., Singh, C. \& Kennett, B.L.N. 2015. A review of crust and upper mantle structure beneath the Indian subcontinent. Tectonophysics 644-645: 1-21.

Spector, A. \& Grant, F.S. 1970. Statistical model for the interpreting aeromagnetic data. Geophysics 35(2): 293-302.

Treitel, S., Clement, W.G. \& Kaul, R.K. 1971. The spectral determination of depths to buried magnetic basement rocks. Geophysical Journal International 24(4): 415-428.
Zhu, L. \& Kanamori, H. 2000. Moho depth variation in Southern California from teleseismic receiver functions. Journal of Geophysical Research: Solid Earth 105(B2): 2969-2980.

Nurul Fairuz Diyana Bahrudin*, Umar Hamzah \& Wan Zuhairi Wan Yaccob

Geology Programme

School of Environmental Sciences and Natural Resources

Faculty of Science and Technology

Universiti Kebangsaan Malaysia

43600 UKM Bangi Selangor Darul Ehsan

Malaysia

Nurul Fairuz Diyana Bahrudin

Environmental Tracer Application Group Waste

Technology and Environmental Division

Malaysian Nuclear Agency, Bangi

43000 Kajang, Selangor Darul Ehsan

Malaysia

*Corresponding author; email: nurulfairuz@nuclearmalaysia. gov.my

Received: 31 May 2019

Accepted: 8 March 2020 